\title{
Modeling the Impact of Land Cover Changes on Soil Erosion Estimation in Yewa North and Yewa South, Ogun State, Nigeria
}

\author{
Lamidi R.B., Okonufua E., Fakeye A.M, and Ayegba M.O \\ Nigerian Building and Road Research Institute (NBRRI) \\ Nigeria
}

\begin{abstract}
Soil erosion is becoming a serious problem in some communities in Yewa North and Yewa South because of rapid land use developments. This study was carried out to analyses the landcover change effects on soil erosion to determine the extent and trend of changes in the study area; estimate and characterize soil loss, and comparing the annual soil loss at different spatial scales. The extent and trend of changes in the landcover were estimated using Landsat Satellite Imageries for the year 2002 and 2017. RUSLE model was used to estimate soil loss and was characterized based on the expert description for tolerable soil loss concept. The results revealed the built-up area showed a consistent increase over time, from $349.5 \mathrm{~km}^{2}$ in 2002 to $592 \mathrm{~km}^{2}$ in 2017 of the total area. The vegetation covered about $933.4 \mathrm{~km}^{2}$ in 2002 but decreased to $509 \mathrm{~km}^{2}$ in 2017. Similarly, the area covered by bare ground increased from $243.7 \mathrm{~km} 2$ in 2002 to $620.4 \mathrm{~km} 2$ in 2017 but the waterbody increased from $0.29 \mathrm{~km}^{2}$ in 2002 to $0.72 \mathrm{~km}^{2}$ in 2017. The areas covered by agriculture also decreased from $1088.5 \mathrm{~km}^{2}$ in 2002 to $894 \mathrm{~km}^{2}$ in 2017. The estimated soil loss values ranged from $0-420,276 \mathrm{tha}^{-}{ }^{1} \mathrm{yr}_{-}{ }^{1}$ with the mean of 231 and standard deviation 2272 in

2002 while the soil loss estimated in 2017 ranged from $0-186,920 t$ ha/ yr. with the mean of 220 and the standard deviation 1312.3. Comparatively, low erosion is observed in a total area of $45.5 \%$ in 2002 and $44.4 \%$ in 2017 while extremely severe erosion is observed in a total area of 29.8\% in 2002 and $34.3 \%$ in 2017 in the study area which matches the actual bareground and agricultural land which can be attributed to change in $C$ and $P$ factors. The study recommended that enlightenment and awareness of erosion control should include land use habit of the people in the agricultural practice and care of vegetation
\end{abstract}

Keyword: Urbanization, Land use Land covers (LULC), Landsat Satellite Imageries, RUSLE model.

\section{INTRODUCTION}

Land use and land cover changes influence numerous natural procedures, for example, soil erosion, sediment creation, flood, and physical and chemical properties of the soil (Martínez-Casasnovas JA, Sánchez-Bosch 2000; Yang D, Kanae S, Oki T, Koike T, Musiake K (2003); Ochoa P, et al. (2016); Zare M, et al (2017). The land use and cover changes in urban regions is a progressive procedure however a few elements can impact this procedure, most particularly human activities. Urbanization is one of the most groundbreaking human land-use forms in history and is probably going to increment in the coming years. It is commensurate to a close perpetual adjustment of the common habitat and it wipes out the locally prevailing regular environment. Urbanization enormously affects common natural surroundings and assets, and urban development is liable for anthropogenic exercises, for example, infringement of horticultural exercises on woods zones, deforestation for business and modern purposes, and general abuse of the land. These exercises change the landuse from its unique vegetation cover to a state of lesser vegetation cover, bringing about soil disintegration (Cebecauer and Hofierka 2008). Urban development because of expanding populace and human exercises, for example, agriculture, deforestation, construction, grazing, and sand mining were distinguished as components that have upgraded the improvement of chasms and this thusly has prompted the devastation of building establishment and correspondence course and arrangement of barren wilderness in the region. Soil erosion is a typical common occurrence that can be ascribed to specific geology, soils, and relating vegetation that prevail and the broad precipitation that the locale encounters.

In Nigeria, the Soil erosion issue is a worldwide phenomenon influencing both the biotic and socio-economy of the encompassing individuals (Ofomata, 1984). One of the anthropogenic variables affecting soil erosion is landuse change. In such a manner, much work has been done to consider the effect of landuse change on soil erosion in different areas (Feng, X et al, 2010; Ranzi, R.; Le, T.H.; Rulli, M.C.2012; Conforti, M.; Buttafuoco, G 2017). In Yewa environs, the phenomenon of soil erosion is likewise boundless. It happened in various Communities which can be affected by quantities of variables both characteristic and anthropogenic and satisfactory records of the soil erosion are not accessible. Evaluating soil erosion is hard to execute because the 
customary overview and planning procedures are costly and tedious for the estimation of land cover changes and soil erosion. Therefore, increased research intrigue is being coordinated to the checking of urban development and soil erosion utilizing GIS and far off detecting procedures (Epstein et al., 2002). Distinctive erosion models have been created in the earlier decades, utilizing different diverse scientific techniques and modeling approaches is essential to the national turn of events. (Isikwue, Abutu, and Onoja, 2012). The integration of remote sensing and geographic information system (GIS) and modeling are significant apparatuses for planning peril and hazard. In this investigation, the Revised Universal Soil Loss Equation (RUSLE) has been incorporated with remote sensing and geographic information system (GIS) to survey soil erosion, for sufficient data on soil erosion that help in legitimate control for land and water use arranging. The combined utilization of GIS and erosion models has been demonstrated to be a successful way to deal with assessing spatial dissemination of erosion

The study, therefore, seeks to analyses the landcover change effects on the soil erosion; by determining the extent and trend of landcover changes in the study area; estimate and characterize soil loss, and comparing the annual soil loss. The study aimed to provide information for effective soil erosion prevention and water conservation planning.

\section{METHOD AND MATERIAL}

\subsection{The Study Area}

The study seeks to analyses the landcover change effects on soil erosion in Yewa North and south. Yewa North and south are located in Ogun State, Southwestern Nigeria. The study area occupies a land area of $2684.3 \mathrm{~km}^{2}$ and a population of 350,676 . The study area is situated between Latitude $6^{\circ} 40^{, \mathrm{N}}$ and $7^{\circ} 25^{, \mathrm{N}}$ Longitude $2^{\circ} 40^{, \mathrm{E}}$ and $3^{\circ} 5^{, \mathrm{E}}$ in the southwestern part of the State with the annual rainfall varying between $105 \mathrm{~cm}$ to $128 \mathrm{~cm}$. The average monthly temperature ranges from $23^{\circ} \mathrm{C}$ in $\mathrm{July}$ to $32^{\circ} \mathrm{C}$ in February. The State has two main types of vegetation viz-tropical rain forest and Guinea savanna. The tropical rain forest is found in the coastal areas of the southern part of Yewa South LGA while the rest are Guinea savanna

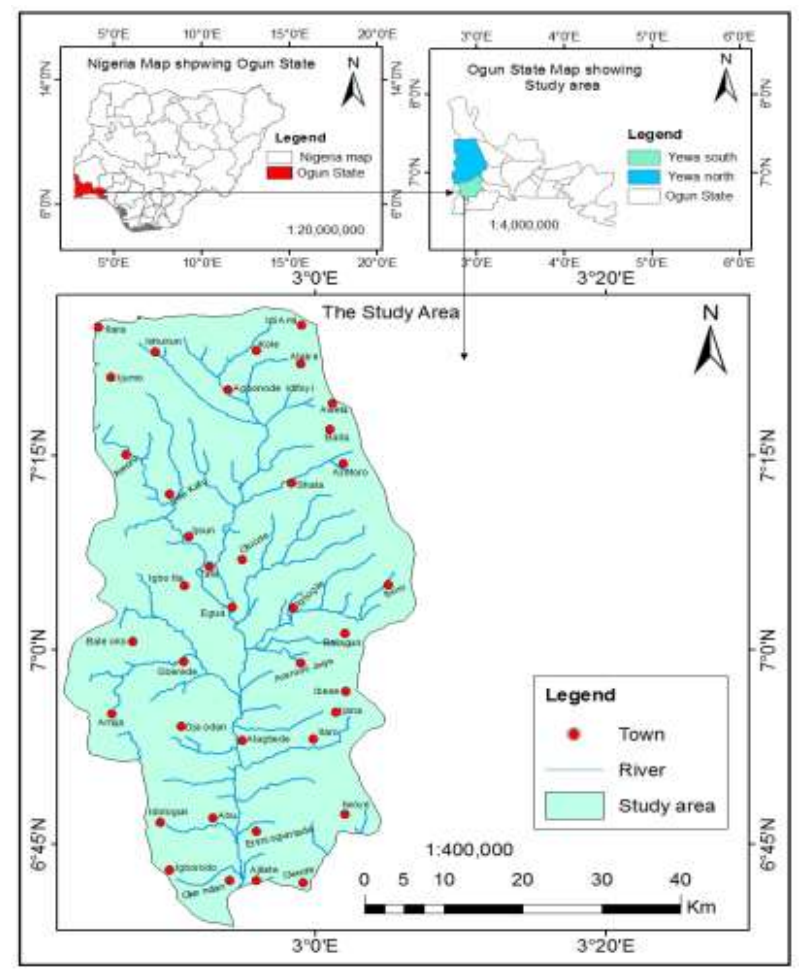

Figure 1: The study area

\subsubsection{Data and sources}

This investigation included both primary and secondary sources of data (Table .1). The primary data includes visiting the study area to acquire the point of erosion area while the secondary include an administrative map of Nigeria, precipitation data, topographic data, soil data, and landuse data 
Table 1: Datasets, Characteristics, Sources, and Relevance

\begin{tabular}{|c|c|c|c|c|}
\hline $\mathrm{S} / \mathrm{N}$ & Source & Year & Characteristics & Relevance \\
\hline 1 & $\begin{array}{l}\text { United State Geological Survey } \\
\text { (USGS) }\end{array}$ & $\begin{array}{l}2002 \\
2017\end{array}$ & $\begin{array}{l}\text { (Path } 191 \text { and row 55) } \\
\text { Resolution } 30 \mathrm{~m}\end{array}$ & $\begin{array}{l}\text { Landuse to generate } \mathrm{C}, \mathrm{P} \\
\text { factor }\end{array}$ \\
\hline 2 & $\begin{array}{l}\text { Tropical Rainfall Measuring } \\
\text { Mission (TRIMM) }\end{array}$ & $\begin{array}{l}1998- \\
2017\end{array}$ & $\begin{array}{l}20 \text { years, Resolution: } \\
\text { resampled to } 30 \mathrm{~m}\end{array}$ & To generate ( $\mathrm{R}$ factor) \\
\hline 3 & $\begin{array}{l}\text { Shuttle Radar Topographic Mission } \\
\text { (SRTM }\end{array}$ & - & $30 \mathrm{~m}$ resolution & To generate LS factor \\
\hline 4 & $\begin{array}{l}\text { Nigerian Building and Road } \\
\text { Research Institute (NBRRI) }\end{array}$ & 2015 & $\begin{array}{l}\text { Resolution: resampled to } \\
30 \mathrm{~m}\end{array}$ & $\begin{array}{l}\text { To generate Soil Erodibility } \\
\text { Factor }\end{array}$ \\
\hline 5 & Global Positional System (GPS) & 2018 & $\begin{array}{l}\text { Landuse references and } \\
\text { points of erosion area. }\end{array}$ & For training site \\
\hline
\end{tabular}

\subsection{Data Processing and Analysis}

\subsubsection{The extent and trend of land cover changes in the study area}

Multi-temporal Landsat images; 2002 and 2017 were processed with ENVI 5.1 and the image was enhanced for visualization purposes, the study area was extracted out of the full scene. The Maximum Likelihood Classifier was used to produce different periods of land cover (LC) maps, after which it was embellished using Arc Map 10.4. The landcover classes were used to generate the cover management map and support practice.

\subsubsection{Soil Loss Estimation}

Revived Universal Soil Loss Equation (RUSLE) was adopted to estimate soil loss. The model is widely used in predicting soil erosion because it can be easily parameterizing The RUSLE model can be calculated using equation 1 (Wischmeier and Smith, 1978; Renard et al., 1997)

$\mathrm{A}=\mathrm{R} \times \mathrm{K} \times \mathrm{LS} \times \mathrm{C} \times \mathrm{P}$.

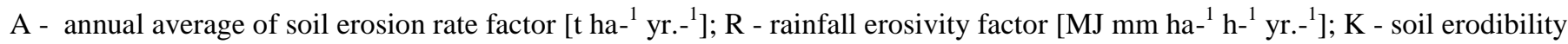
factor [t ha- $\left.{ }^{1} \mathrm{~h}^{-1} \mathrm{MJ} \mathrm{mm}-{ }^{1}\right]$; LS - slope length and gradient factor (dimensionless); C - crop management factor (dimensionless, ranged between 0 and 1); while $\mathrm{P}$ is the conservation support practice which is dimensionless and ranged between 0 and 1 ). All five factors were developed as raster with $30 \mathrm{~m} \times 30 \mathrm{~m}$ cell size using spatial analysis extension of ArcGIS software.

\subsubsection{The Rainfall Erosivity ( $R$ factor)}

The daily rainfall data from 1998 - 2002 and 2013 - 2017 acquired were entered into excel creating a database of average annual rainfall to generate the rainfall erosivity. The rainfall erosivity was calculated using Lee and Lee equation as shown in Table 2

Table 2: Equation for RUSLE parameter

\begin{tabular}{lll}
\hline Equation & Parameters & Source \\
$\mathrm{R}=38.5+0.35 \times \mathrm{Pr}$ & Rainfall Erosivity & Lee and Lee, 2006 \\
$K=7.594 *\left(0.0034+0.0405 * \exp \left[^{-0.5} *(\log (D g)+1.659\right.\right.$ & Soil erodibility & Renard et al. 1997 \\
$\left./ 0.7101)^{2}\right]$ & & \\
$\mathrm{Dg}(\mathrm{mm})=\exp ^{0.01 * \operatorname{sum}(f i \ln m c+f i \ln m s i+f i \ln m s a)}$ & $\mathrm{DG}$ & Renard et al. 1997 \\
$L S=\left(\frac{F A \times C S}{22.13}\right) m \times\left[0.065+0.045(S)+0.0065\left(S^{2}\right)\right]$ & LS factor & Bizwuerk et al. (2008) \\
\hline
\end{tabular}

\subsubsection{Soil erodibility (K) factor}

The soil data collected were entered into excels creating a database that includes percentages of sand, clay, silt, and soil types. Each soil type based on textural classification of the United States Department of Agriculture classification (USDA) were assigned with erodibility value using geometric mean particle diameter $(\mathrm{Dg})$. A new field was created in the soil type attribute table titled $\mathrm{K}$ factor value. The soil type map was converted from polygon to raster using the $\mathrm{K}$ factor value as a value field to produce the K factor map. The equation from Renard et al. 1997 was used to compote the Kfactor aa shown in table 2

\subsubsection{Estimating LS factor}

A Digital Elevation Model (DEM) of 30m resolution from the Shuttle Radar Topographic Mission (SRTM) was downloaded. The DEM was imported into ArcGIS software to generate the different raster layer which includes; slope gradient, flow direction, and flow accumulation to generate slope length and slope steepness (LS factor) 


\subsubsection{Cover Management Factor $(C)$ and conservation practice $(P)$ factor}

The cover management factor $(\mathrm{C})$ and conservation practice $(\mathrm{P})$ factor values were derived for each type of landcover classes based on the different expert description (Table 3). A new field was created in the landuse attribute table titled $\mathrm{C}$ factor value and $\mathrm{P}$ factor value. The landuse map was converted from polygon to raster using the $\mathrm{C}$ factor value and $\mathrm{P}$ factor value as the value field to produce $\mathrm{C}$ factor map and $\mathrm{P}$ factor map. The soil loss was estimated by multiplying the entire RUSLE parameter utilizing the Raster Calculator. The result generated was reclassed to improve visualization.

Table $3 \mathrm{C}$ and $\mathrm{P}$ factor values for each land cover classes

\begin{tabular}{lllll}
\hline S/N & Landcover classes & Cfactor & Pfactor & source \\
1 & Agricultural land & 0.3 & 0.40 & Lee \& Lee 2006 \\
2 & Bare ground & 0.35 & 0.45 & Jung (2004) \\
3 & Built-up land & 0.1 & 1 & Jung (2004) \\
4 & Vegetation & 0.03 & 0.1 & Ministry of forestry, 1985 \\
5 & Waterbody & 0 & 0.5 & Lee \& Lee 2006 \\
\hline
\end{tabular}

Source: Soo (2008)

\section{RESULT AND DISCUSSION}

\section{1 The extent and trend of landcover changes in the study area}

Five classes of landcover were identified from satellite imagery classification. The result of the accuracy assessment of the image classified shows that the overall accuracy is $82 \%$ and the kappa coefficient is 0.76 . The result indicates that $76 \%$ of image classification agreed with the reference data. Landis and Koch (1977) represented the value of accuracy to be (0.61 to 0.80). Based on this author's suggestion, the strength of agreement is thereby categorized as good. The producer's accuracy and user's accuracy of each class are shown in Table 4. High User's accuracy was recorded in waterbody (97\%) built-up land (93\%), agricultural land (71\%), and forest $73 \%$ respectively while low User's accuracy was seen in the bare ground (54\%). Low accuracy in the bare ground may be as a result of several problems in the interpretation of land use and confusion among other landuse types.

The results reveals that in the periods 2002, 2017, the spatial extent of built-up area showed a consistent increase over time, from $349.5 \mathrm{~km}^{2}(13.35 \%)$ in 2002 to $592 \mathrm{~km}^{2}(22.6 \%)$ in 2017 of the total area. The vegetation decreased from $933.4 \mathrm{~km}^{2}(35.7 \%)$ in 2002 to $509 \mathrm{~km}^{2}(19.45 \%)$ in 2017 . Similarly, the area covered by water body increased from $0.29 \mathrm{~km}^{2}(0.01 \%)$ in 2002 to $0.72 \mathrm{~km}^{2}$ $(0.02 \%)$ in 2017 ; while the areas covered with bare ground increased from $244 \mathrm{~km}^{2}(9.32 \%)$ to $620.4 \mathrm{~km}^{2}(23.72 \%)$ in 2017 and agricultural land decreased from $1088.5 \mathrm{~km}^{2}(41.62 \%)$ in 2002 to $894 \mathrm{~km}^{2}(34.2 \%)$ in 2017

Table 4: Distribution and spatial extent of landcover in 2002 and 2017

\begin{tabular}{llllll}
\hline & \multicolumn{2}{c}{2002} & \multicolumn{5}{c}{2017} \\
Class Name & Area $\mathrm{km}^{2}$ & Area\% & Area km & Area\% & Trend \\
Builtup Area & 349.5 & 13.35 & 592 & 22.6 & 9.25 \\
Agricultural land & 1089 & 41.62 & 894 & 34.2 & -7.42 \\
Vegetation & 933.4 & 35.7 & 509 & 19.45 & -16.25 \\
Bare ground & 244 & 9.32 & 620.4 & 23.72 & 14.4 \\
Waterbody & 0.29 & 0.01 & 0.72 & 0.03 & 0.02 \\
& 2616.19 & 100 & 2616.12 & 100 & \\
\hline
\end{tabular}




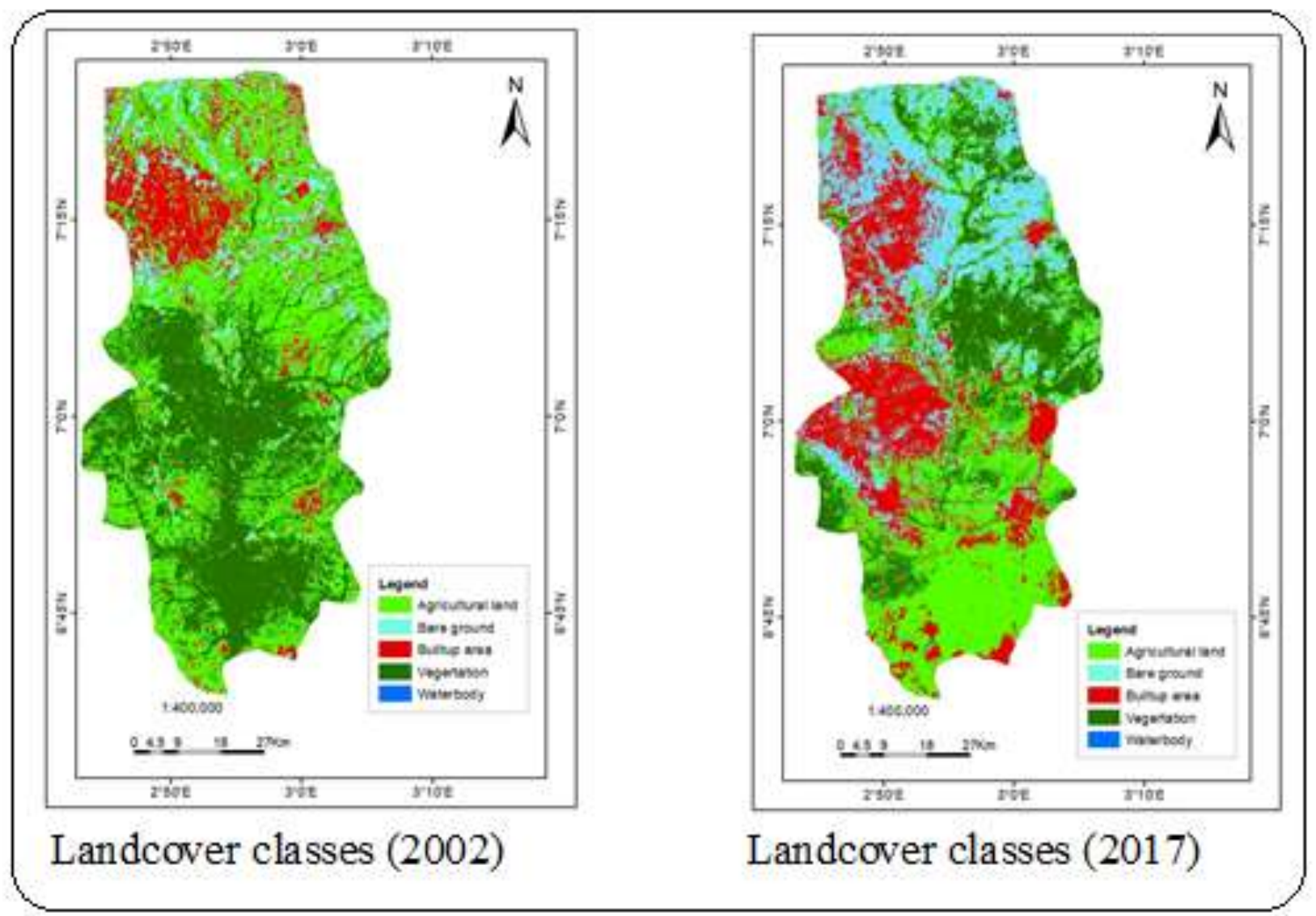

Figure 2: Landcover classes for 2002 and 2017

\subsection{RUSLE Factors}

\subsubsection{The rainfall erosivity ( $R$ factor)}

Table 5 shows the estimated average annual rainfall value ranges from 2951.98 -3161.36 in 2002 while the average annual rainfall value for 2017 ranges from 2937.98 - 3200.44. The $\mathrm{R}$ factor values estimated for 2002 range from $1071.69-1140.79 \mathrm{MJ} /$ mm\&ha ${ }^{1} \mathrm{hr}^{1}$ /year with the mean of 1098.6 while R factor value estimated ranges from 1066.79 to $1151.07 \mathrm{MJ} / \mathrm{mm} \&$ ha1 $\mathrm{hr} .1$ /year with the mean of 1098.6 as shown in Figure 3.

Table 5: Average annual rainfall

\begin{tabular}{lll}
\hline point & \multicolumn{1}{c}{2002} & \multicolumn{1}{c}{2017} \\
& Ave.annual Rainfall $(\mathrm{mm})$ & Ave.annual Rainfall $(\mathrm{mm})$ \\
801 & 3161.36 & 3200.44 \\
802 & 3075.5 & 3148.36 \\
848 & 3128.08 & 3030.24 \\
849 & 3147.84 & 3015.62 \\
895 & 3002.78 & 2980.44 \\
896 & 2951.98 & 2937.98 \\
\hline
\end{tabular}




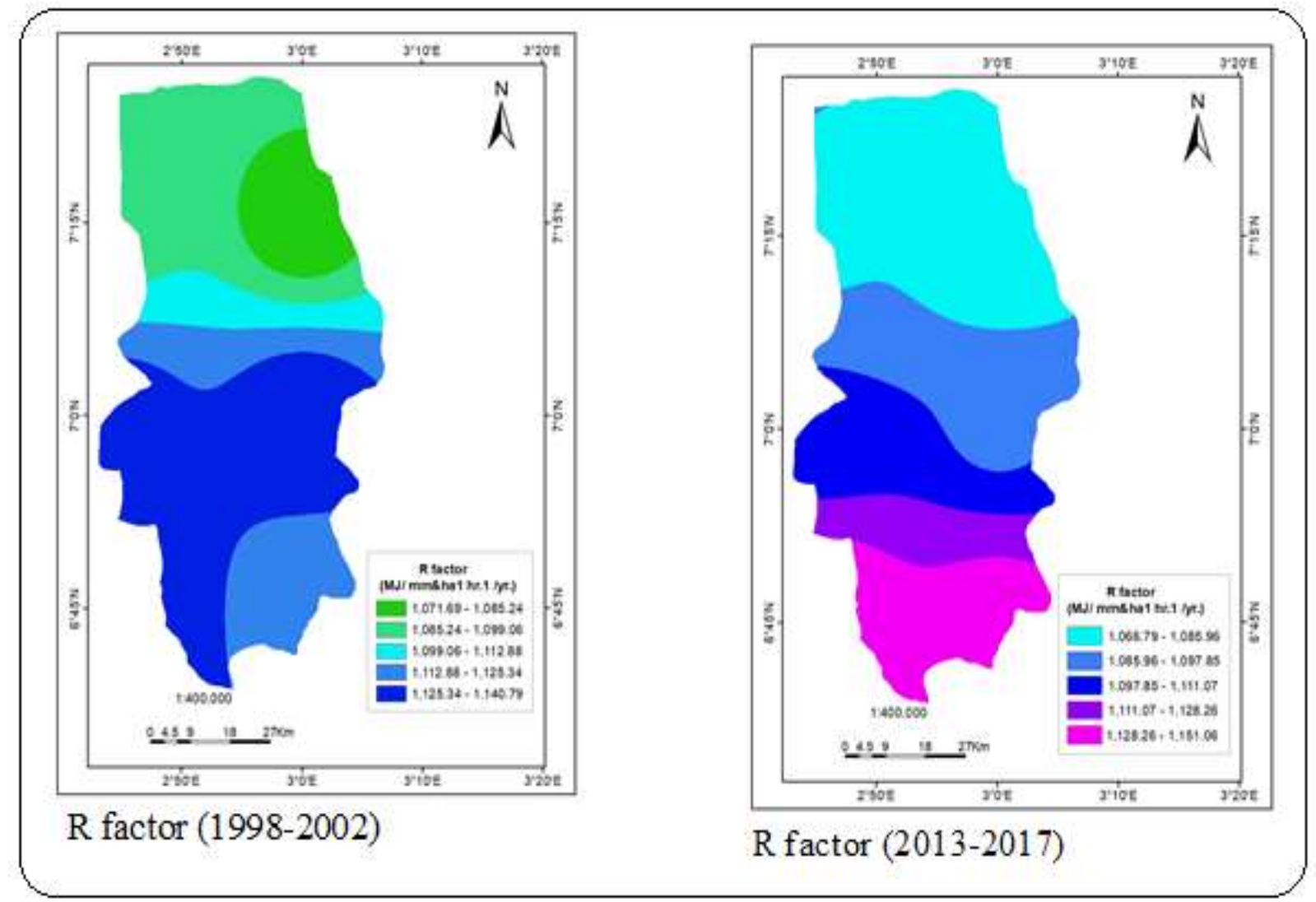

\section{Figure 3: The $\mathbf{R}$ factor for 2002 and 2017}

\subsubsection{Soil erodibility (K Factor)}

The USDA textural classification of soil in the study area comprises loamy fine sand, fine sand, sandy clay loam, clay loam, clay, and loam as in Figure 6. The values obtained for $\mathrm{K}$ factor for each sample are shown in Figure 7 where $\mathrm{K}$ value ranges from 0.02 to $0.19 \mathrm{t} \mathrm{ha-}{ }^{1} \mathrm{~h}-{ }^{1} \mathrm{MJ} \mathrm{mm}-{ }^{1}$ with a total mean of 0.10 and the standard deviation was 0.03 . The result also reveals that higher erodibility values is associated with soils having high silt content and lower value of $\mathrm{K}$ factor is associated with the soils having low permeability, low antecedent moisture content.

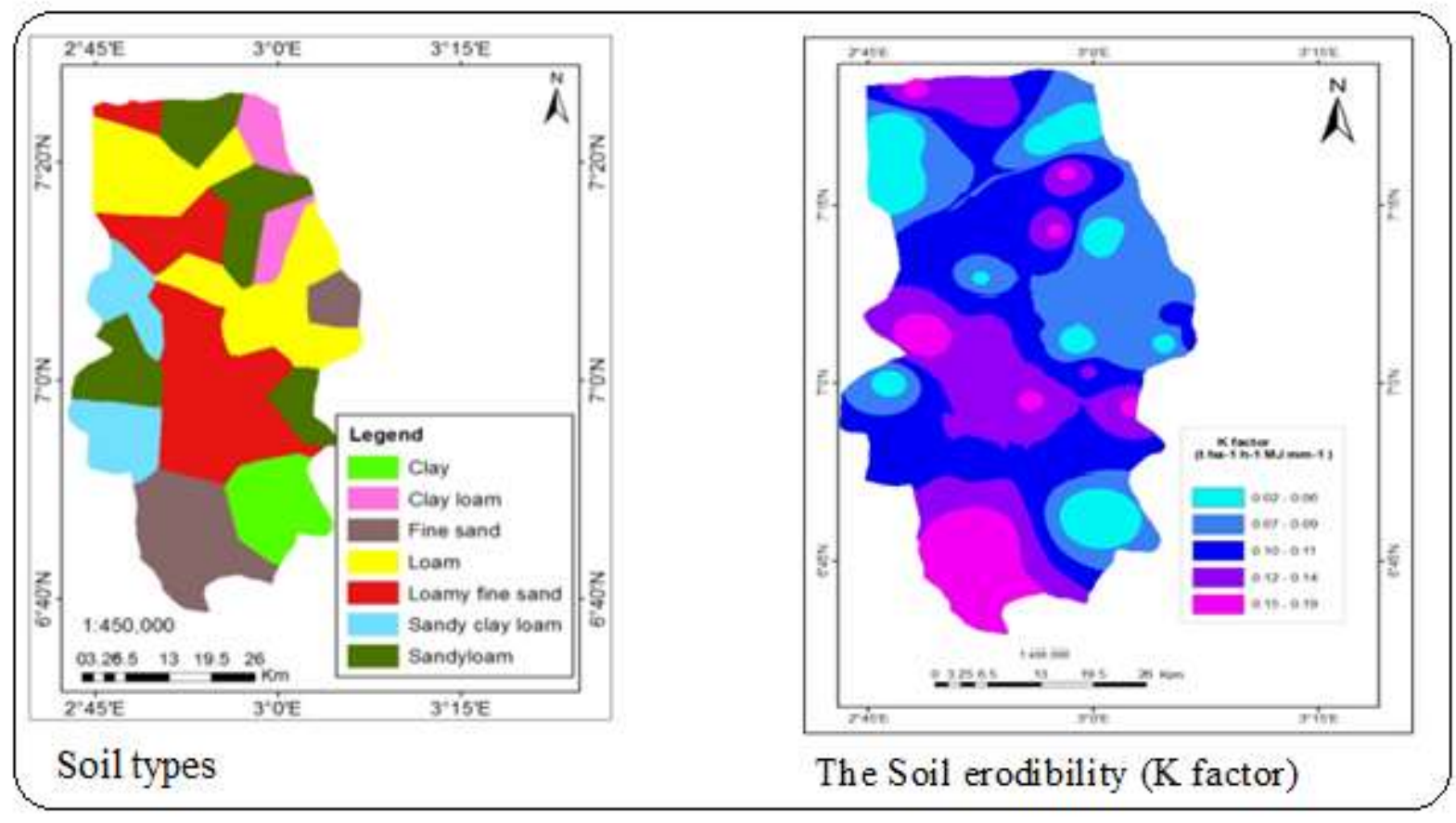

Figure 4: Soil types and Soil erodibility (K factor) 


\subsubsection{Estimating LS factor}

The LS factor provides better identification of problematic areas that will affect soil erosion. Figure 5 shows the different raster layers for slope length and steepness (LS) factor. The LS factor value ranges from 0 to 157.8 with a mean and standard deviation of 0.29 and 1.3 respectively. The estimated LS result shows that $91.7 \%$ of the total study area has a value greater than $15 \%$ while $8.3 \%$ of the total area falls under the LS values that is less than $15 \%$ as shown in Table 7 and Figure 6 . The highest values corresponded with the greater slope while the lowest value corresponded to the study area lowlands. The average LS value is 0.29 which implies that study area land belongs to a low-risk class (0 - 2 unit) based on the grading standards of Manrique (1988).

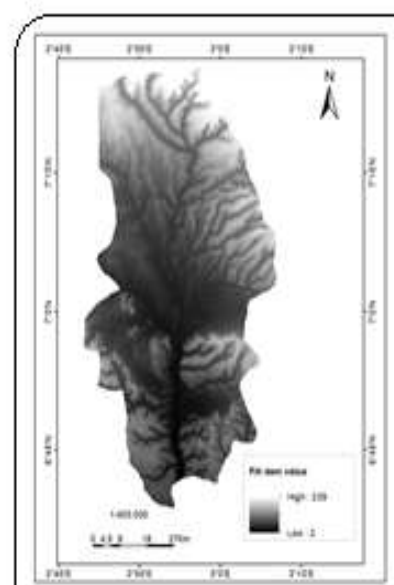

Fill DEM

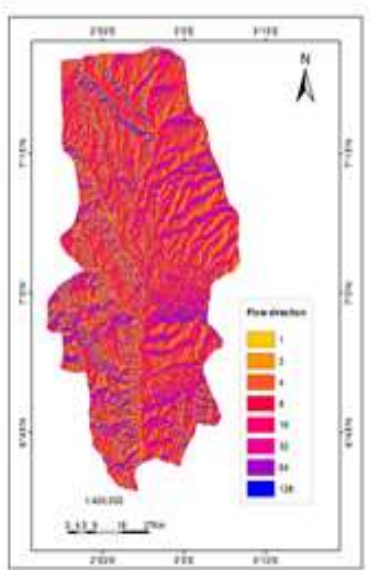

Flow direction

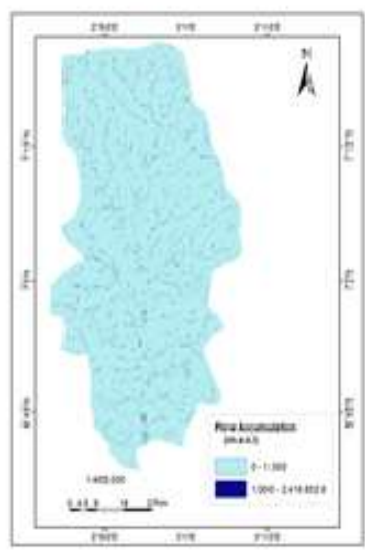

Flow accumulation

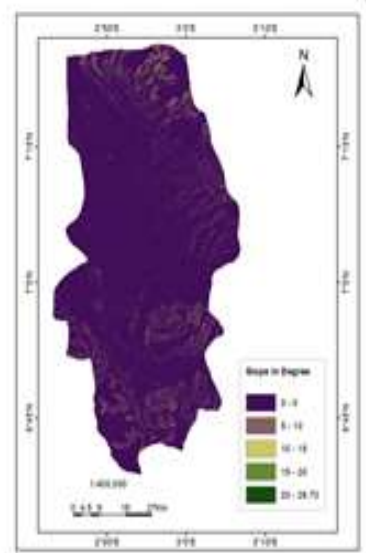

Slope map

Figure 5: Different raster layer for slope length and steepness (LS) factor

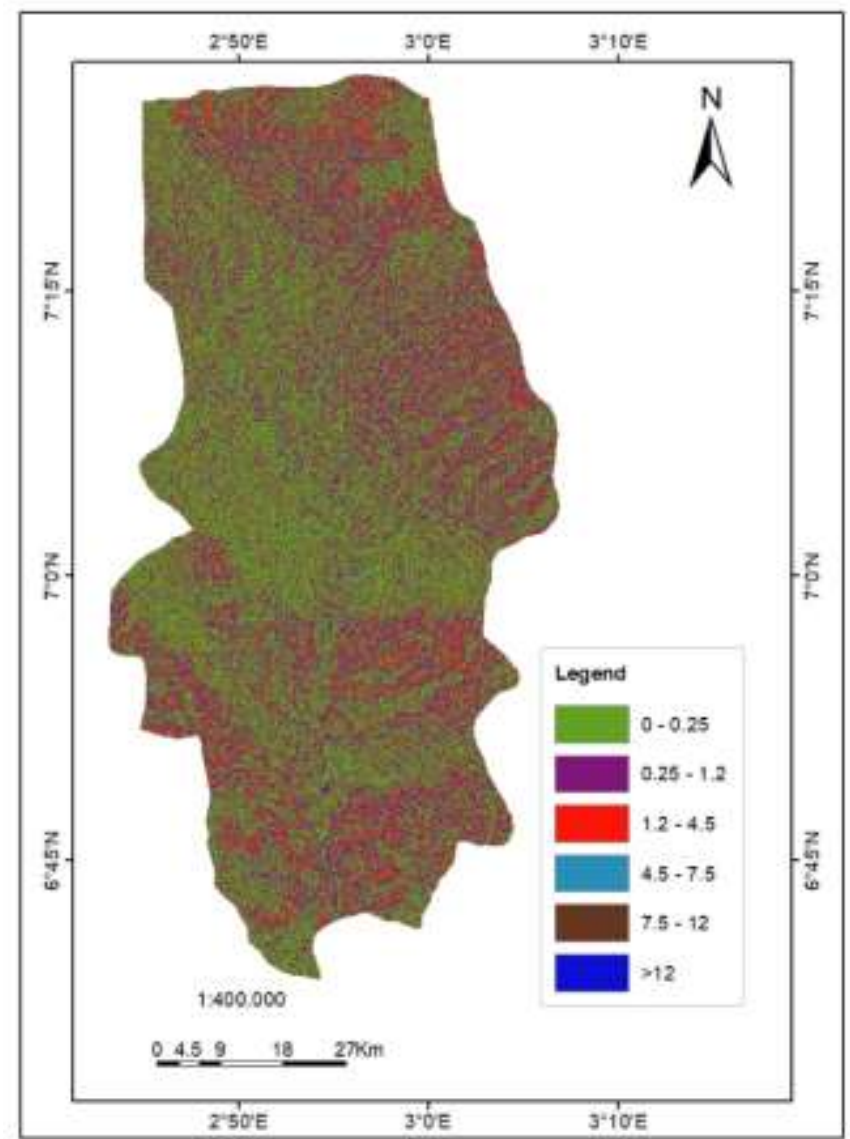

Figure 6: LS factor map 
Table 6: Slope gradient and Slope Length Index (LS)

$\begin{array}{llll}\text { Slope } \% & \text { LS value } & \text { Areakm2 } & \text { Area\% } \\ 0-5 & 0-0.25 & 1458 & 55.9 \\ 5-15 & 0.25-1.2 & 935.13 & 35.8 \\ 15-35 & 1.2-4.25 & 188.11 & 7.2 \\ 35-45 & 4.25-7.5 & 15 & 0.6 \\ 45-50 & 7.5-12 & 6.4 & 0.3 \\ >50 & >12 & 5.5 & 0.2 \\ & & 2608.14 & 100\end{array}$

\subsubsection{Cover Management Factor $(\mathrm{C})$}

The cover management factor $(\mathrm{C})$ values range from $0-0.35$ with a mean of 2.38 and 2.98, and a standard deviation of 1.29 and1.33. Table 7 and Figure 8 show the Spatial distribution of Cfactor values. Higher values of $\mathrm{C}$ factor imply no cover effect and soil loss similar to that from a tilled bare fallow, while lower $\mathrm{C}$ means a very strong cover effect indicating no erosion effect (Erencin, 2000). The result reveals that about $35.7 \%$ of the total area has a strong cover effect indicating no erosion. The study area is mostly covered by agriculture activities ( $41.62 \%$ and $34.2 \%$ respectively) which are the direct relation between the $\mathrm{C}$ factor and soil loss

Table 7: Distribution and spatial extent of $\mathrm{C}$ factor

\begin{tabular}{llllcl}
\hline Class Name & \multicolumn{2}{c}{2002} & \multicolumn{2}{c}{2017} & Cfactor \\
& Area km & Area\% & Area km & Area\% & \\
Builtup Area & 349.5 & 13.35 & 592 & 22.6 & 0.1 \\
Agricultural land & 1089 & 41.62 & 894 & 34.2 & 0.3 \\
Vegetation & 933.4 & 35.7 & 509 & 19.45 & 0.03 \\
Bare ground & 244 & 9.32 & 620.4 & 23.72 & 0.35 \\
Waterbody & 0.29 & 0.01 & 0.72 & 0.03 & 0 \\
& 2616.19 & 100 & 2616.12 & 100 & \\
\hline
\end{tabular}

Source: Authors Analysis, (2019)

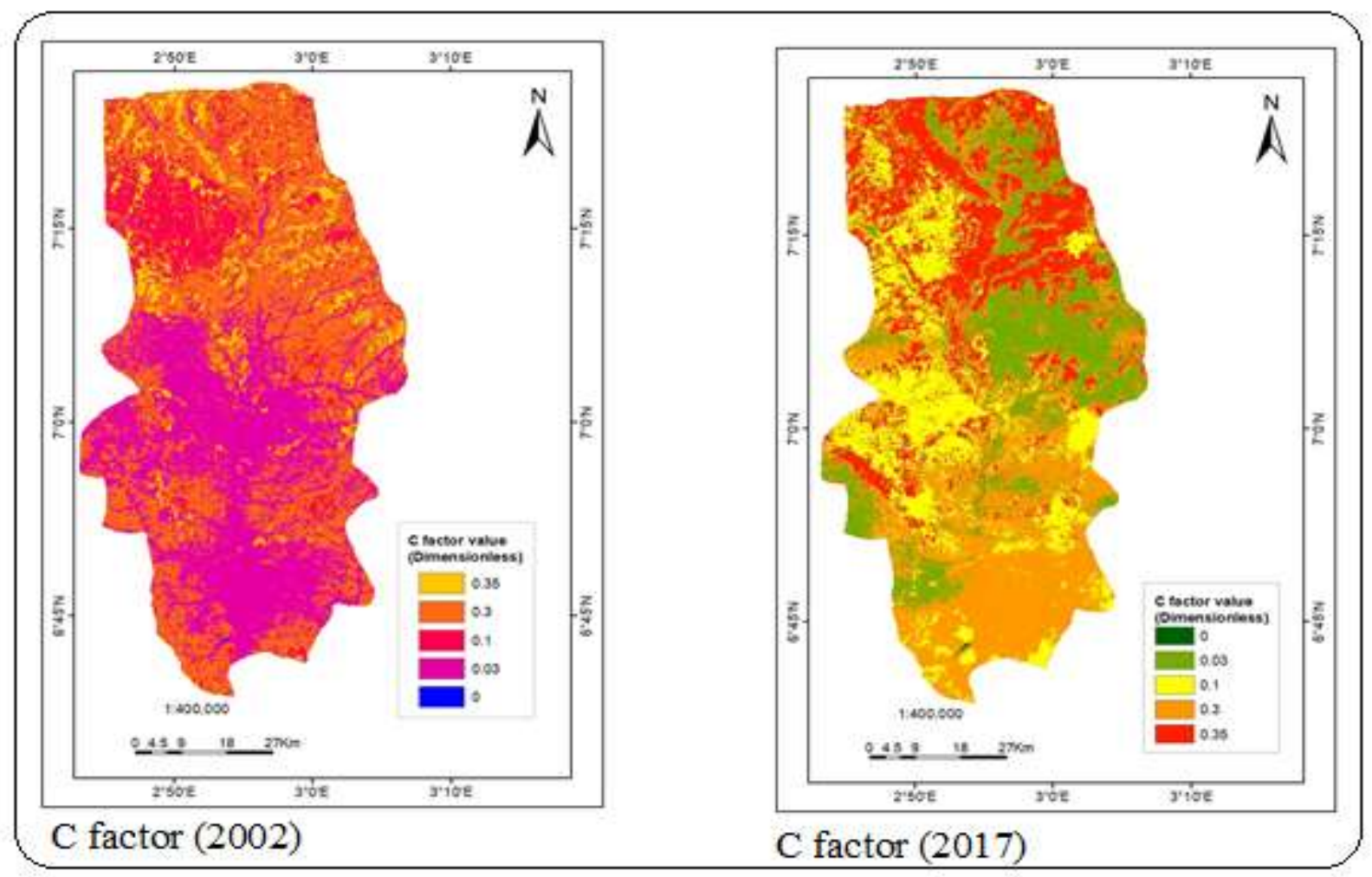

Figure 8. Cover Management Factor (C) 


\subsubsection{Support practice factor $(\mathbf{P})$}

The support practice factor was estimated based on the different Land cover as shown in Table 8 . The P factor values range from 0.1 - 1 with a mean of 2.13 in 2002 and 2.98 in 2017, and a standard deviation of 1.29 in 2002 and1.33 in 2017 as shown in Figure 9. The lower the p-value, the more the effect the conservation.

Table 8: Distribution and spatial extent of $P$ factor

\begin{tabular}{llllcl}
\hline Class Name & \multicolumn{2}{c}{2002} & \multicolumn{2}{c}{ Pfactor } \\
& Area km & Area\% & Area km & Area\% & \\
Builtup Area & 349.5 & 13.35 & 592 & 22.6 & 1 \\
Agricultural land & 1089 & 41.62 & 894 & 34.2 & 0.4 \\
Vegetation & 933.4 & 35.7 & 509 & 19.45 & 0.1 \\
Bare ground & 244 & 9.32 & 620.4 & 23.72 & 0.65 \\
Waterbody & 0.29 & 0.01 & 0.72 & 0.03 & 0.5 \\
\hline
\end{tabular}

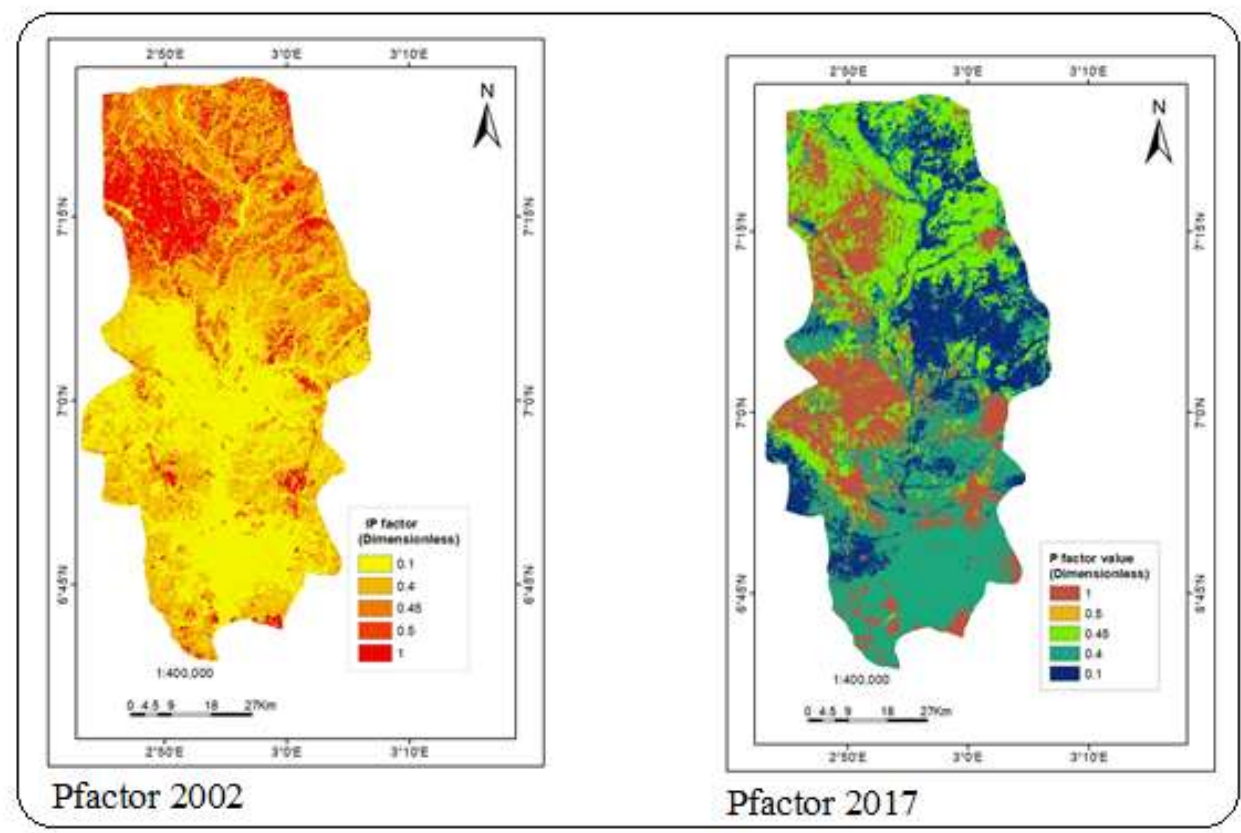

Figure 9: Support practice factor $(\mathbf{P})$

\subsection{Estimation of Soil Loss and extent of soil loss}

Figure 10 shows the estimation of soil loss using Revived universal soil loss equation (RUSLE) and the values range from 0 $186,920 \mathrm{t}$ ha/ $\mathrm{yr}$. with the mean of 220 and the standard deviation 1312.3 in the year 2017 while the soil loss estimated in 2002 ranges from $0-420,276 \mathrm{tha}^{-1} \mathrm{yr}^{-}{ }^{1}$ with the mean of 231 and standard deviation 2272 . Based on the results of the RUSLE model, the study area was divided into 5 classes in terms of soil erosion in two study years and it indicates soil sensitivity to erosion. The

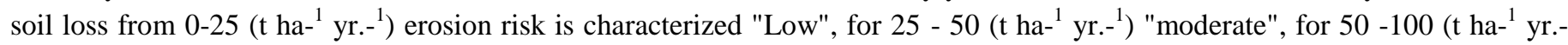

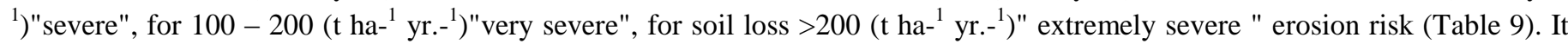
was observed that in the year 2002, $45.5 \%$ of the total area falls under low soil loss, followed by $29.8 \%$ of the total area that comes under extremely severe soil loss. The soil loss classes of moderate, severe and very severe covers $8.2 \%, 8.6 \%$ and $7.9 \%$ of the total area respectively while in $201744.4 \%$ of the total area falls under the low soil loss, followed by $34.3 \%$ of the total area that comes under extremely severe soil loss and soil loss classes of moderate, severe and very severe covers $5.2 \%, 6.4 \%$ and $9.7 \%$ of the total area respectively. 
Table 9: Erosion Risk level based on (FAO) in (1979),

\begin{tabular}{llllll} 
Soil erosion potential & \multicolumn{2}{c}{2002} & \multicolumn{2}{c}{ Area } \\
$(\mathrm{t}$ ha-1 year-1) & Area $\left(\mathrm{km}^{2}\right)$ & Area $(\%)$ & Area $\left(\mathrm{km}^{2}\right)$ & Area $(\%)$ & Changes rate $(\%)$ \\
Low $(0-25)$ & 1187.6 & 45.5 & 1104.4 & 44.4 & -1.1 \\
Moderate $(25-50)$ & 212.6 & 8.2 & 130.2 & 5.2 & -3 \\
Severe $(50-100)$ & 225.2 & 8.6 & 159.2 & 6.4 & -2.2 \\
Very severe $(100-200$ & 207.1 & 7.9 & 240.6 & 9.7 & 1.8 \\
Extremely severe $(>200)$ & 776.1 & 29.8 & 851.1 & 34.3 & 4.5 \\
\hline
\end{tabular}

Source; Authors Analysis, (2019)

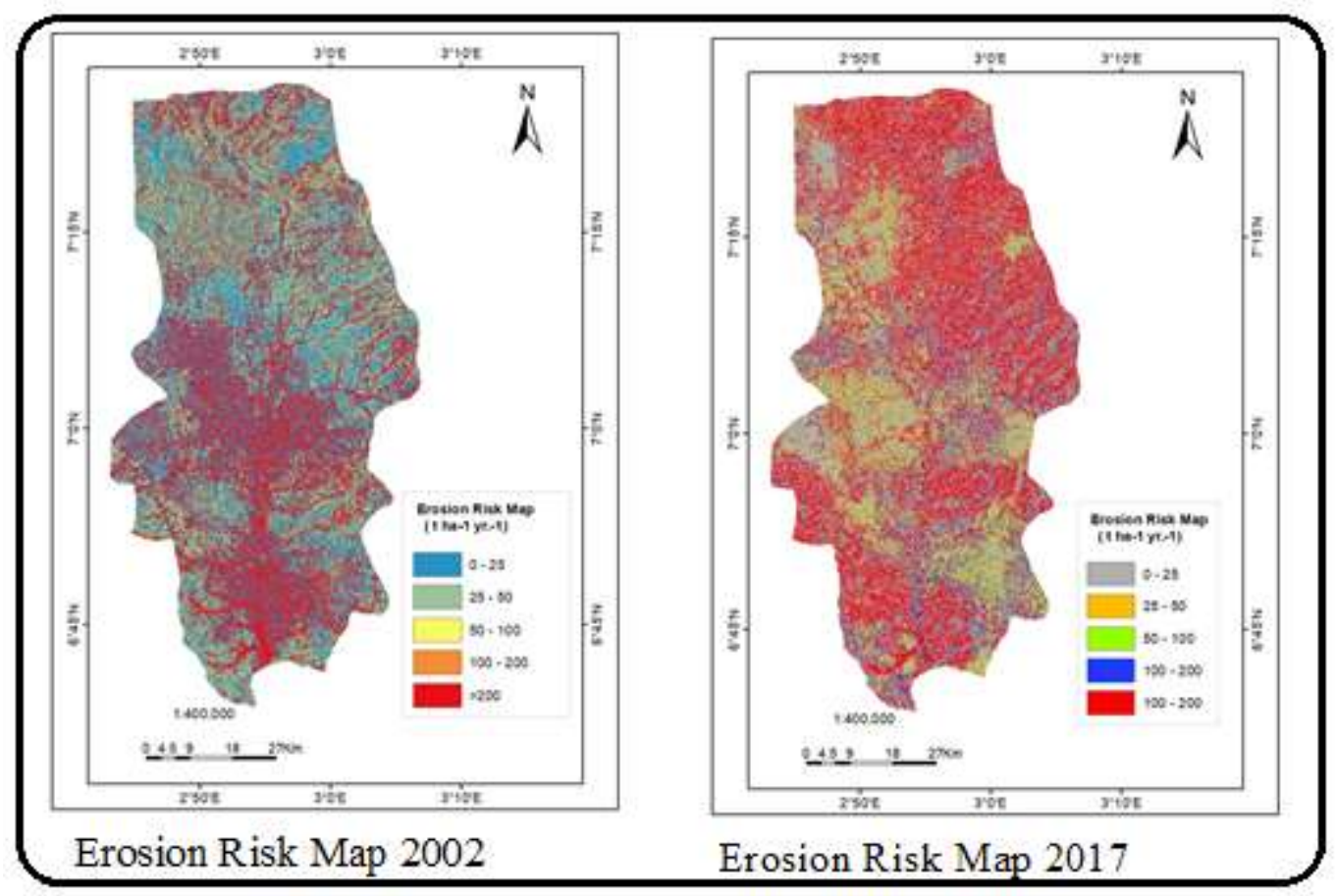

Figure 10: The Erosion Risk Map

\subsection{Discussion}

From 2002 to 2017 periods witnessed significant urban expansion, this indicates a remarkable increase in the urban built-up areas, up to twice what was obtained at the beginning of the period. This rapid rate of urban expansion has been found to have encroached greatly into other urban landcover. For instance, as the population grew in the study area, agricultural land, and vegetation began to decrease to support the increasing need for land to support residential, commercial, and institutional development. This result corresponded with Ramachandran, 2001; Mary and Raghavaswamy, 2000 and Madhavi et al., 2004 investigation which demonstrated that the city has been seeing fast development in the urban populace somewhere in the range of 1981 and 1999. The result from soil erodibility that range from 0.1 to 0.19 agrees with Renard et al., (1991) report where K values can range from about 0.10 to 0.45 -ton acre ${ }^{-1}$ U.S customary units $\left(0.01\right.$ to 0.5 -ton ha $\mathrm{h} \mathrm{ha}^{-1} \mathrm{MJ}^{-1} \mathrm{~mm}^{-1}$ SI metric units

The study also shows that there is an increase in the rate of soil loss in the study area. The mean rate of soil loss in 2002 is 231.88 t ha- ${ }^{1}$ yr. ${ }^{-}$. and 219.79 t ha- $^{1}$ yr. ${ }^{1}$. in 2017 . Comparatively, low erosion is observed in a total area of $45.5 \%$ in 2002 and $44.4 \%$ in 2017 while extremely severe erosion is observed in a total area of $29.8 \%$ in 2002 and $34.3 \%$ in 2017 in the study area. The extremely severe soil loss was found to be distributed mainly within the areas of moderate to high slope gradient while the estimated soil loss was relatively much lower on plain sites compared to the high slope lands.

Among the five RUSLE factors, the LS and K factor remains the same. Except for the R factor was found to be less during 2017 when compared to 2002. The land cover in the study area comprises of agricultural land, vegetation, bare ground, builtup land, and waterbody. Among the landcover classes, the agricultural lands, and bare ground experiencing high erosion along the extreme slope and vegetation areas were least eroded or had low to moderate erosion. The soil loss value was found to be more during 2002 because the R factor was higher but it is significantly different in prediction between 2002 and 2017 result concerning landscape, higher erosion risk level rate was estimated concerning landscape $34.3 \%$ in 2017 against the $29.8 \%$ in 2002 which can be attributed to change in $\mathrm{C}$ and $\mathrm{P}$ factor. These factors are directly linked to land cover change which is the ultimate result of urbanization. Determining soil loss rates helps in understanding the efforts needed to save the physical quality of land and ultimately holds valuable information for developing necessary conservation strategies. 


\subsection{CONCLUSION AND RECOMMENDATION}

The general objective of the study is to examine the effects of urban growth on soil loss. In achieving the objective, this study applied Remote Sensing and GIS techniques with the RUSLE model. The Revised Universal Soil Loss Equation (RUSLE) model was categorized into four classes of erosion risk ranges from a low, medium, high, and very high soil loss.

Based on the result and findings of this research, there is significantly different in predicted result between 2002 and 2017 concerning landscape, higher erosion risk level rate was estimated concerning landscape and it is obvious that soil erosion is becoming a serious ecological problem in some places within the study area. To curb the menace of soil erosion and improve sustainable management in this area, it is recommended that

i. Farming practices should be improved to reduce the soil erosion processes to the barest minimum through proper enlighten on the danger of poor farming techniques.

ii. The traditional method of erosion control which is found to be cheap and effective (i.e. planting of plantain and banana on the floodplains) should be adopted

iii. Adequate awareness of the effects of human activities that promote soil erosion on both floodplain and river channels should be encouraged in these areas.

\section{REFERENCES}

1. Martínez-Casasnovas JA, Sánchez-Bosch I (2000) Impact assessment of changes in land use/conservation practices on soil erosion in the Penedès- Anoia vineyard region (NE Spain). Soil Tillage Res 57: 101-106.

2. Yang D, Kanae S, Oki T, Koike T, Musiake K (2003) Global potential soil erosion with reference to land use and climate changes. Hydrological processes 17: 2913-2928.

3. Zare M, Samani AN, Mohammady M, Salmani H, Bazrafshan J (2017) Investigating effects of land use change scenarios on soil erosion using CLUE-s and RUSLE models. Int J Environ Sci Technol 14: 1905-1918.

4. Ochoa P, Fries A, Mejía D, Burneo J, Ruíz-Sinoga J, et al. (2016) Effects of climate, land cover and topography on soil erosion risk in a semiarid basin of the Andes. Catena 140: 31-42.

5. Cebecauer T, Hofierka J (2008) The consequences of land-cover changes on soil erosion distribution in Slovakia. Geomorphology 98:187-198

6. Ofomata, G.E.K. (1984)' Erosion in the forest zone of Nigeria 'A Paper presented at the $27^{\text {th }}$ Annual Conference of Geographical Association of Nigeria, University of Nigeria, Nsukka.

7. Feng, X.; Wang, Y.; Chen, L.; Fu, B.; Bai, G. Modeling soil erosion and its response to land-use change in hilly catchments of the Chinese Loess Plateau. Geomorphology 2010, 118, 239-248.

8. Ranzi, R.; Le, T.H.; Rulli, M.C. A RUSLE approach to model suspended sediment load in the Lo river (Vietnam): Effects of reservoirs and land use changes. J. Hydrus. 2012, 422, 17-29.

9. Conforti, M.; Buttafuoco, G. Assessing space-time variations of denudation processes and related soil loss from 1955 to 2016 in southern Italy (Calabria region). Environ. Earth Sci. 2017, 76, 457

10. Wischmeier, W.H., and Smith, D.D. (1978). Predicting rainfall erosion losses - A guide to conservation planning.US Department of Agriculture, Science, and Education Administration. Agriculture handbook 537. Washington

11. Renard, K. G., Foster, G. R., Weesies, G. A., McCool, D., and Yoder, D. (1997). Predicting Soil Erosion by Water: A Guide to Conservation Planning with the Revised Universal Soil Loss Equation (RUSLE). Agriculture Handbook (Washington) (703

12. Lee, G.S., and Lee, K.H. (2006). Scaling effect for estimating soil loss in the RUSLE model using remotely sensed geospatial data in Korea. Hydrology and Earth System Sciences Discussions 3, 135-157.Korea Water Resource Corporation, 462-1 Jeonmin-dong, Yusung-gu, Daejeon, Korea.

13. Bizuwerk, A., Taddese, G., and Getahun, Y. (2008) Application of GIS for Modeling Soil Loss Rate in A Wash Basin, Ethiopia. International Livestock Research Institute, Addis Ababa, Ethiopia

14. Soo H. T. (2011). Soil Erosion Modeling using RUSLE and GIS on Cameron Highlands, Malaysia for Hydropower Development Published M.Sc. Thesis The School for Renewable Energy Science in affiliation with University of Iceland \& University of Akureyri, Akureyri

15. Mary Ashalata \& Raghavaswamy, V. (2000). Remote sensing and GIS-based study on 'Air Quality and Land Use / Cover Hotspot Characterization in Hyderabad City, Andhra Pradesh, India. NNRMS bulletin (B)-25, 30-36

16. Ramachandran, Kausalya. (2001). Assessment of contamination of Natural Resource using GIS and Remote Sensing - a study of the Hyderabad region. GIS India - Jan - Feb 2001, 8 -13.

17. Madhavi Lata., Krishna Prasad, K, V., Badarinath, K. V. S., \& Raghavaswamy, V. (2004). Measuring urban sprawl: A case study of Hyderabad 